\title{
Does Foreign Direct Investment Increase the Productivity of Domestic Firms? In Search of Spillovers through Backward Linkages
}

\author{
Beata Smarzynska Javorcik
}

July 23, 2003

\begin{abstract}
Many countries strive to attract foreign direct investment (FDI) in the hope that knowledge brought by multinationals will spill over to domestic industries and increase their productivity. In contrast with earlier literature that failed to find positive intra-industry spillovers from FDI, this study focuses on effects operating across industries. The analysis, based on a firm-level panel data set from Lithuania, produces evidence consistent with positive productivity spillovers from FDI taking place through contacts between foreign affiliates and their local suppliers in upstream sectors. The data indicate that such spillovers are associated with projects with shared domestic and foreign ownership but not with fully owned foreign investments. There is no indication of spillovers occurring within the same industry or through domestic firms sourcing inputs from multinationals.
\end{abstract}

Keywords: spillovers, foreign direct investment, technology transfer

JEL classification: $F 2, O 1, O 3$

\footnotetext{
* The World Bank, 1818 H St., NW, MSN MC3-303, Washington, DC 20433. Tel. (202) 458-8485. Email: bsmarzynska@worldbank.org. I wish to thank Mary Amiti, Enrique Aldaz-Carroll, Andrew Bernard, Simon Evenett, Ana Fernandes, Michael Ferrantino, Caroline Freund, Holger Görg, Mary Hallward-Driemeier, Wolfgang Keller, Pravin Krishna, Hiau Looi Kee, Maryla Maliszewska, Jacques Morisset, Marcelo Olarreaga, Nina Pavcnik, Maurice Schiff, Matt Slaughter, Mariana Spatareanu, Jim Tybout, two anonymous referees, and the participants of the Tuck International Trade Conference, seminar at the Inter-American Development Bank, and the European Research Workshop in International Trade for valuable comments and suggestions. The financial support received from the Foreign Investment Advisory Service (FIAS)--a joint facility of the IFC and the World Bank--is gratefully acknowledged. This paper is part of a larger FIAS effort to improve the understanding of spillovers from multinational corporations to local firms. The views expressed in the paper are those of the author and should not be attributed to the World Bank or its Executive Directors.
} 


\section{Introduction}

Policymakers in many developing and transition economies place attracting foreign direct investment (FDI) high on their agenda, expecting FDI inflows to bring much-needed capital, new technologies, marketing techniques, and management skills. While all of these potential benefits of FDI are viewed as important, particular emphasis is placed on the contribution of FDI to increasing productivity and competitiveness of the domestic industry. It is often hoped that technology transfer resulting from FDI will go beyond actual projects undertaken by foreign investors and, through knowledge spillovers, will benefit domestic firms.

Yet there is no evidence that positive externalities generated by foreign presence actually exist. As Dani Rodrik (1999) remarked, “today's policy literature is filled with extravagant claims about positive spillovers from FDI but the evidence is sobering." Indeed, the difficulties associated with disentangling different effects at play and data limitations have prevented researchers from providing conclusive evidence of positive externalities resulting from FDI. While recent firm-level studies have overcome many of the difficulties faced by earlier literature, the emerging message is not very optimistic.

The existing literature on this subject is of three kinds. First, there are case studies, which are often very informative and include a wealth of valuable information (see, for instance, Moran 2001) but because they pertain to particular FDI projects or specific countries, they cannot be easily generalized. Then, there is a plethora of industry-level studies, most of which show a positive correlation between foreign presence and the average value added per worker in the sector. Because most of them rely on cross-sectional data, their disadvantage is the difficulty in establishing the direction of causality. It is possible that this positive association is caused by the fact that multinationals tend to locate in high-productivity industries rather than by genuine productivity spillovers. The positive correlation may also be a result of FDI inflows forcing less productive domestic firms to exit and/or of multinationals increasing their share of host country market, both of which would raise the average productivity in the industry. ${ }^{1}$ Finally, there is

\footnotetext{
${ }^{1}$ The pioneering work on this issue done by Caves (1974) focused on Australia. It was followed by studies looking at Mexico where, due to the large technological gap between foreign and domestic firms, the scope for spillovers may have been higher (see Blomström and Persson 1983; Blomström and Wolff 1994; and the summary of studies on Mexican data by Blomström 1989). Note that the criticism regarding reverse causality does not apply to all industry-level research, as some studies looked at changes taking place between two points in time (Blomström 1986 on Mexico) or relied on panel data (Liu et al. 2000 on the UK) and still concluded that there exist positive spillovers from FDI.
} 
research based on firm-level panel data, which examines whether the productivity of domestic firms is correlated with the extent of foreign presence in their sector. Most of these studies, however, such as the careful analyses done by Haddad and Harrison (1993) on Morocco, Aitken and Harrison (1999) on Venezuela, and Djankov and Hoekman (2000) on the Czech Republic, cast doubt on the existence of spillovers from FDI in developing countries. The researchers either fail to find a significant effect or produce evidence of negative horizontal spillovers, that is, the effect the presence of multinational corporations has on domestic firms in the same sector. The picture is more optimistic in the case of industrialized countries, as the recent work by Haskel, Pereira, and Slaughter (2002) and Keller and Yeaple (2003) provides convincing evidence of positive FDI spillovers in the United Kingdom and the United States, respectively. ${ }^{2}$

It is possible, though, that researchers have been looking for FDI spillovers in the wrong place. Since multinationals have an incentive to prevent information leakage that would enhance the performance of their local competitors, but at the same time may benefit from transferring knowledge to their local suppliers, spillovers from FDI are more likely to be vertical than horizontal in nature. In other words, spillovers are most likely to take place through backward linkages, that is, contacts between domestic suppliers of intermediate inputs and their multinational clients, and thus they would not have been captured by the earlier studies. ${ }^{3}$ It is also plausible that spillovers from multinational presence in upstream sectors exist thanks to provision of inputs that either were previously unavailable in the country or are technologically more advanced, less expensive, or accompanied by provision of complementary services. As Blomström, Kokko, and Zejan (2000) point out, hardly any empirical studies analyze vertical spillovers. The notable exceptions are recent papers by Blalock (2001) employing firm-level panel data from Indonesia and by Schoors and van der Tol (2001) relying on cross-sectional enterprise-level information from Hungary, both of which provide evidence of positive FDI spillovers through backward linkages. ${ }^{4}$

The purpose of this study is twofold. First, it examines whether the productivity of domestic firms is correlated with the presence of multinationals in downstream sectors (potential

\footnotetext{
${ }^{2}$ For surveys of the literature on spillovers from FDI see Görg and Strobl (2001) and Lipsey (2002).

${ }^{3}$ For a theoretical justification of spillovers through backward linkages, see Rodriguez-Clare (1996), Markusen and Venables (1999), and Saggi (2002). For case studies, see Moran (2001).

${ }^{4}$ Kugler (2000) also finds intersectoral technology spillovers from FDI in Colombia. However, he does not distinguish between different channels through which such spillovers may be occurring (for example, backward versus forward linkages).
} 
customers) or upstream industries (potential suppliers of intermediate inputs). Detecting such effects would be consistent with the existence of vertical spillovers. The analysis improves over the recent literature by taking into account econometric problems that may have biased the results of earlier work. Namely, the semiparametric estimation method suggested by Olley and Pakes (1996) is employed to account for endogeneity of input demand. Moreover, standard errors are corrected to take into account the fact that the measures of potential spillovers are industry specific while the observations in the data set are at the firm level. As Moulton (1990) pointed out, failing to make such a correction will lead to a serious downward bias in the estimated errors, thus resulting in a spurious finding of statistical significance for the aggregate variable of interest.

Second, this study goes beyond the existing literature by shedding light on determinants of vertical spillovers. It examines whether benefits stemming from vertical linkages are related to the extent of foreign ownership in affiliates. Based on case studies and investor surveys, these factors have been conjectured to influence the reliance on local sourcing on the part of multinationals and thus the potential benefits of backward linkages, but to the best of our knowledge, their impact has not been systematically examined. ${ }^{5}$

The analysis is based on data from the annual enterprise survey conducted by the Lithuanian Statistical Office. The survey coverage is extensive, as firms accounting for about 85 percent of output in each sector are included. The data constitute an unbalanced panel covering the period 1996-2000. Focusing on a transition economy such as Lithuania is very suitable for this project, as the endowment of skilled labor enjoyed by transition countries makes them a particularly likely place for productivity spillovers to manifest themselves. ${ }^{6}$

The findings can be summarized as follows. The empirical results are consistent with the existence of positive spillovers from FDI taking place through backward linkages, but there is no robust evidence of spillovers occurring through either the horizontal or the forward linkage channel. In other words, the productivity of Lithuanian firms is positively correlated with the extent of potential contacts with multinational customers but not with the presence of multinationals in the same industry or the existence of multinational suppliers of intermediate

\footnotetext{
${ }^{5}$ See UNCTC (2001, chapter 4) for a comprehensive review of this topic.

${ }^{6}$ For instance, during 1990-2000 the number of scientists and engineers in research and development activities per million people was equal to 2,031 in Lithuania, compared to 2,139 in Korea, 711 in Argentina, 168 in Brazil, and 154 in Malaysia (Global Economic Indicators, 2002, World Bank).
} 
inputs. The magnitude of the effect is economically meaningful. A one-standard-deviation increase in the foreign presence in the sourcing sectors is associated with a 15 percent rise in output of each domestic firm in the supplying industry. The productivity effect is found to originate from investments with joint foreign and domestic ownership but not from fully owned foreign affiliates, which is consistent with the evidence of a larger amount of local sourcing undertaken by jointly owned projects.

This study is structured as follows: The next section gives a brief overview of spillover channels. Section III discusses FDI inflows into Lithuania, the data, and the estimation strategy. The results are presented in Section IV, and Section V presents conclusions.

\section{Overview of Spillover Channels}

Spillovers from FDI take place when the entry or presence of multinational corporations increases the productivity of domestic firms in a host country and the multinationals do not fully internalize the value of these benefits. Spillovers may take place when local firms improve their efficiency by copying technologies of foreign affiliates operating in the local market either through observation or by hiring workers trained by the affiliates. Another kind of spillover occurs if multinational entry leads to more severe competition in the host country market and forces local firms to use their existing resources more efficiently or to search for new technologies (Blomström and Kokko 1998).

To the extent that domestic firms and multinationals operating in the same sector compete with one another, the latter have an incentive to prevent technology leakage and spillovers from taking place. This can be achieved through formal protection of their intellectual property, trade secrecy, paying higher wages to prevent labor turnover, or locating in countries or industries where domestic firms have limited imitative capacities to begin with. ${ }^{7}$ This observation is consistent with the results of recent studies that failed to produce evidence of positive horizontal spillovers from FDI.

\footnotetext{
${ }^{7}$ Several studies (Aitken, Harrison, and Lipsey 1997; Girma, Greenaway, and Wakelin 2001) have documented that foreign firms pay higher wages than domestic firms. Multinationals have also been found to be sensitive to the strength of intellectual property rights protection in host countries (see Javorcik, forthcoming).
} 
On the other hand, multinationals have no incentive to prevent technology diffusion to upstream sectors, as they may benefit from improved performance of intermediate input suppliers. Thus, backward linkages - that is, contacts between multinational firms and their local suppliers-should be the most likely channel through which spillovers would manifest themselves. These spillovers may take place through (i) direct knowledge transfer from foreign customers to local suppliers; ${ }^{8}$ (ii) higher requirements for product quality and on-time delivery introduced by multinationals, which provide incentives to domestic suppliers to upgrade their production management or technology; ${ }^{9}$ and (iii) multinational entry increasing demand for intermediate products, which allows local suppliers to reap the benefits of scale economies.

Similarly, domestic firms may become more productive as a result of gaining access to new, improved, or less costly intermediate inputs produced by multinationals in upstream sectors (forward linkage channel). Sales of these inputs by multinationals may be accompanied by provision of complementary services that may not be available in connection with imports.

Anecdotal evidence confirms spillovers taking place through backward linkages in transition countries. For instance, after a Czech producer of aluminum alloy castings for the automotive industry signed its first contract with a multinational customer, the staff from the multinational would visit the Czech firm's premises for two days each month over an extended period to work on improving the quality control system. Subsequently, the Czech firm applied these improvements to its other production lines (not serving this particular customer) and reduced the number of defective items produced. ${ }^{10}$

The results of a recent enterprise survey conducted in Latvia (FIAS 2003) are consistent with our expectation of positive spillovers taking place through backward linkages but are ambiguous with respect to the intra-industry effect. The evidence from Latvia is particularly relevant as, besides being neighboring countries, Lithuania and Latvia share many similarities in terms of their history and economic conditions. The survey demonstrated that a majority of

\footnotetext{
${ }^{8}$ As numerous case studies indicate (see Moran 2001), multinationals often provide technical assistance to their suppliers in order to raise the quality of their products or facilitate innovation. They help suppliers with management training and organization of the production process, quality control, purchase of raw materials, and even finding additional customers. Note that the existence of linkages does not necessarily guarantee that spillovers take place, nor does the fact that multinationals may charge for services provided preclude the presence of spillovers. Spillovers take place when foreign affiliates are unable to extract the full value of the resulting productivity increase through direct payment or lower prices they pay for intermediates sourced from the local firm.

${ }^{9}$ For instance, many multinationals require their suppliers to obtain International Standards Organization (ISO) quality certifications.

${ }^{10}$ Source: Interview with company management conducted by the author in the Czech Republic in May 2003.
} 
multinationals are engaged in local sourcing -82 percent of those interviewed had at least one Latvian supplier of intermediate inputs, and on average, 47 percent of intermediate inputs purchased by foreign firms came from Latvian producers. Thirty-six percent of Latvian firms supplying multinationals reported receiving assistance from their customers. As far as horizontal spillovers are concerned, one-third of Latvian firms stated that they have benefited from the presence of foreign firms in their sector (15 percent through sourcing inputs from multinationals, 14 percent by learning about new technologies, and 9 percent by learning about new marketing strategies). At the same time, 45 percent of survey respondents reported that foreign entry increased competition in their industry, with 6.5 percent of firms admitting to having lost market share to foreign firms. As Aitken and Harrison (1999) pointed out, knowledge spillovers within an industry may be counterbalanced by the competition effect; that is, as domestic firms lose market share to foreign entrants, they experience lower productivity since their fixed costs are spread over a smaller market. Thus, the reported increase in competition levels due to foreign entry is consistent with the lack of intra-industry spillovers found in the current analysis.

Different types of FDI projects may have different implications for vertical spillovers. For instance, it has been argued that affiliates established through mergers and acquisitions or joint ventures are likely to source more locally than those taking the form of greenfield projects (UNCTC 2001). While the latter have to put time and effort into developing local linkages, the former can take advantage of the supplier relationships of the acquired firm or its local partners. Empirical evidence to support this view has been found for Japanese investors (Belderbos, Capannelli, and Fukao 2001) and for Swedish affiliates in Eastern Europe (UNCTC 2000). Unfortunately, in the data set used here it is impossible to distinguish among the three types of foreign investment. However, to the extent that full foreign ownership is a proxy for greenfield projects, it is expected that fully owned foreign affiliates will tend to rely more on imported inputs, while investment projects with shared domestic and foreign ownership will tend to source more locally. ${ }^{11}$ This hypothesis is supported by the survey mentioned above, which showed that while over half of partially owned foreign affiliates operating in Latvia purchased their intermediate inputs locally, the same was true of only 9 percent of fully owned foreign

\footnotetext{
${ }^{11}$ There may exist greenfield projects undertaken jointly by foreign and local entities but in that case they should be lumped together with joint ventures, as the participation of a local company brings access to domestic suppliers. This classification will, however, be problematic in the case of full acquisitions undertaken by foreigners.
} 
subsidiaries (FIAS 2003). Similarly, the results of a study of the largest exporters in Hungary (Toth and Semjen 1999) indicate that foreign affiliates with larger shares of foreign equity tend to purchase fewer inputs from Hungarian companies. In sum, it is expected that larger spillovers are associated with partially rather than fully owned foreign projects.

\section{Data and Estimation Strategy}

\section{A. Foreign Direct Investment in Lithuania}

Like other former Soviet Republics, Lithuania had been virtually closed to foreign investment until 1990, when it regained its independence and began the process of transition to a market economy. The first stage of the privatization process, starting in 1991, offered limited opportunities for foreign investors. It was not until 1997 that FDI inflows into Lithuania increased significantly, as a result of the second stage of the privatization program. As illustrated in Chart 1, FDI inflows peaked in 1998, when 60 percent of shares of Lietuvas Telekomas (Lithuanian Telecom), the fixed-line monopoly operator, were sold to Amber Teleholdings, a consortium of Swedish Telia and Finish Sonera (EBRD 2001). ${ }^{12}$ Due to its late start, Lithuania has attracted less FDI than have other Central and Eastern Europe countries (CEECs). Cumulative FDI inflows during the period 1993-2000 reached US\$694 per capita, placing Lithuania seventh among CEECs, above Slovenia, Bulgaria, and Romania. In terms of the value of cumulative FDI inflows, Lithuania ranks eighth, above Estonia and Slovenia (see Table 1).

As far as sectoral distribution of FDI is concerned, 44 percent of the FDI stock in 1996 was in manufacturing. After large inflows into the telecommunications and financial sectors, this figure decreased to 32 percent in 2000. Within manufacturing, food products, beverages, and tobacco attracted the largest share of investment (12 percent of total FDI stock), followed by textiles and leather products ( 4 percent) and refined petroleum and chemicals (4 percent). Electrical machinery, optical instruments, and wood products also received significant foreign investments (OECD 2000). A detailed distribution of FDI stock in 2000 within the two-digit

\footnotetext{
${ }^{12}$ Note that the large jump in FDI inflows due to this transaction does not affect the results of this paper, as only manufacturing sectors are included in the econometric analysis.
} 
manufacturing sectors, calculated on the basis of the data set used in the study, is presented in the first column in Table 2.

Lithuania's population, gross domestic product (GDP), and, not surprisingly, FDI inflows are concentrated in three principal cities: Vilnius, Kaunas, and Klaipeda. At the beginning of 2000, Vilnius accounted for 60.5 percent of the country's total FDI, with the other two cities accounting for 10.5 and 11.6 percent, respectively. Direct investment in manufacturing sectors is concentrated around Klaipeda, while the bulk of FDI inflows into wholesale and retail trading are found in the capital city of Vilnius (OECD 2000, 2001).

\section{B. Data Description}

The data used in this study come from the annual enterprise survey conducted by the Lithuanian Statistical Office. The survey coverage is extensive, as firms accounting for about 85 percent of output in each sector are included in the sample. The Lithuanian enterprise data have been praised for their high quality and reliability. ${ }^{13}$ The data constitute an unbalanced panel covering the period 1996-2000. The number of firms per year varies from a low of twelve thousand in 1996 to a high of twenty-one thousand in 1999. Due to financial constraints in some years, the Statistical Office was forced to reduce the scope of the exercise. In each year, however, the same sampling technique was used.

This study focuses on manufacturing firms (sectors 15-36 in Nomenclature générale des activités économiques dans les Communautés européennes, NACE), which lowers the sample size to 2,500 to 4,000 firms per year. The number of observations is further reduced by deleting those with missing values, zero sales, zero employment, and observations failing to satisfy other basic error checks. Moreover, two sectors-tobacco (NACE 16) and manufacturing of refined petroleum products (NACE 23) - are excluded, since the small number of firms makes it impossible to apply the Olley-Pakes technique (discussed below) to these industries. Thus, the final sample size varies between 1,918 and 2,711 firms in a given year. The sectoral distribution of firms in the last year of the sample is presented in Table 2.

The data set contains information on foreign ownership, sales, inventories, employment, fixed assets, input costs, investment, location, and share of exports in total sales. Firms with

\footnotetext{
${ }^{13}$ A recent study examining the quality of data collected by statistical offices ranked Lithuania second among 20 transition economies (see Belkindas, Dinc, and Ivanova 1999).
} 
foreign capital participation are defined as firms in which the share of subscribed capital (equity) owned by foreign investors is equal to at least 10 percent. More than 12 percent, or 1,414 of the total of 11,630 observations, meet this definition.

Lithuania and other transition countries of Eastern Europe are suitable objects for an analysis of FDI spillovers because of their high endowment of skilled labor, which makes them particularly likely locations for productivity spillovers. On the downside, the brief duration of the panel makes it more difficult to detect the presence of spillovers. Extending the panel to earlier years would not mitigate this problem because of limited FDI presence during the early 1990s. Further, a high level of aggregation in the industry classification (NACE two-digit) and the fact that the data set pertains to firms rather than plants also works against finding a significant spillover effect.

\section{Estimation Strategy}

To examine the correlation between firm productivity and FDI in the same industry or other sectors, an approach similar to that taken by earlier literature is followed and several variations of the following equation are estimated

$$
\begin{gathered}
\ln Y_{i j r t}=\alpha+\beta_{1} \ln K_{i j r t}+\beta_{2} \ln L_{i j r t}+\beta_{3} \ln M_{i j r t}+\beta_{4} \text { Foreign Share }_{i j t}+\beta_{5} \text { Horizontal }_{j t} \\
+\beta_{6} \text { Backward }_{j t}+\beta_{7} \text { Forward }_{j t}+\alpha_{t}+\alpha_{r}+\alpha_{j}+\varepsilon_{i j r t}
\end{gathered}
$$

$Y_{i j r t}$ stands for the real output of firm $i$ operating in sector $j$ and region $r$ at time $t$, which is calculated by adjusting the reported sales for changes in inventories of finished goods and deflating the resulting value by the Producer Price Index for the appropriate two-digit NACE sector. $K_{i j r t}$, capital, is defined as the value of fixed assets at the beginning of the year, deflated by the simple average of the deflators for five NACE sectors: machinery and equipment; office, accounting, and computing machinery; electrical machinery and apparatus; motor vehicles, trailers, and semi-trailers; and other transport equipment. Since in the data set it is impossible to distinguish between skilled and unskilled workers, labor is expressed in terms of efficiency units, which are computed by dividing the wage bill by the minimum wage $\left(L_{i j r t}\right) .{ }^{14} M_{i j r t}$, materials, are equal to the value of material inputs adjusted for changes in material inventories, deflated by an 
intermediate inputs deflator calculated for each sector based on the input-output matrix and deflators for the relevant industries. Finally, Foreign Share ${ }_{i j r t}$ measures the share of firm's total equity owned by foreign investors.

Turning to proxies for spillovers, Horizontal $_{j t}$ captures the extent of foreign presence in sector $j$ at time $t$ and is defined as foreign equity participation averaged over all firms in the sector, weighted by each firm's share in sectoral output. ${ }^{15}$ In other words,

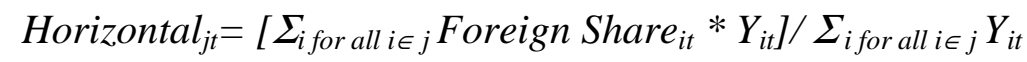

Thus, the value of the variable increases with the output of foreign investment enterprises and the share of foreign equity in these firms.

Backward $_{j t}$ is a proxy for the foreign presence in the industries that are being supplied by sector $j$. It is intended to capture the extent of potential contacts between domestic suppliers and multinational customers. ${ }^{16}$ It is defined as follows:

$$
\text { Backward }_{j t}=\Sigma_{k \text { if } k \neq j} \alpha_{j k} \text { Horizontal }_{k t}
$$

where $\alpha_{j k}$ is the proportion of sector $j$ 's output supplied to sector $k$ taken from the 1996 inputoutput matrix at the two-digit NACE level. The proportion is calculated excluding products supplied for final consumption but including imports of intermediate products. ${ }^{17}$ As the formula indicates, inputs supplied within the sector are not included, since this effect is already captured by the Horizontal variable. ${ }^{18}$ The greater the foreign presence in sectors supplied by industry $j$ and the larger the share of intermediates supplied to industries with a multinational presence, the higher the value of the variable.

The Forward variable is defined as the weighted share of output in upstream (or supplying) sectors produced by firms with foreign capital participation. As only intermediates

\footnotetext{
${ }^{14}$ This approach was pioneered by Griliches and Ringstad (1971) and more recently used by Tybout, de Melo, and Corbo (1991). Note that defining employment as the number of workers yields similar results.

${ }^{15}$ This definition is analogous to that in Aitken and Harrison (1999), who use employment as weights. Blalock (2001) and Schoors and van der Tol (2001) employ output weights but do not take into account the share of foreign equity, treating total output of firms with at least 10 percent foreign equity as foreign.

${ }^{16}$ To illustrate the meaning of the variable, suppose that the sugar industry sells half of its output to jam producers and half to chocolate producers. If no multinationals are producing jam but half of all chocolate production comes from foreign affiliates, the Backward variable will be calculated as follows: $1 / 2 * 0+1 / 2 * 1 / 2=0.25$.

${ }^{17}$ Since relationships between sectors may change over time (although a radical change is unlikely), using multiple input-output matrices would be ideal. Unfortunately, input-output matrices for later years are unavailable. Similarly, while employing a matrix excluding imports would be preferable, such a matrix does not exist. Thus, the results should be interpreted with these two caveats in mind.

${ }^{18}$ Including the share of intermediates supplied within the sector in the Backward measure does not change the conclusions with respect to the correlation between firm productivity and foreign presence in the sourcing sectors.
} 
sold in the domestic market are relevant to this study, goods produced by foreign affiliates for exports $\left(X_{i t}\right)$ are excluded. Thus, the following formula is used:

$$
\text { Forward }_{j t}=\Sigma_{m \text { if } m \neq j} \sigma_{j m}\left[\Sigma_{\text {ifor all i } m} \text { Foreign Share } i t *\left(Y_{i t}-X_{i t}\right)\right] / \Sigma_{i \text { for all i } m}\left(Y_{i t}-X_{i t}\right)
$$

where $\sigma_{j m}$ is the share of inputs purchased by industry $j$ from industry $\mathrm{m}$ in total inputs sourced by sector $j$. For the same reason as before, inputs purchased within the sector are excluded. The value of the variable increases with the share of foreign affiliates in the (domestically sold) output of upstream sectors.

The proxies for horizontal and vertical linkages are time-varying sector-specific variables. While the coefficients taken from the input-output table remain fixed, changes in level of foreign investment and firm output are observed during the period in question. Table 2 lists the values of all three measures in the last year of the sample, 2000.

There is significant variation across sectors and time in all variables. For instance, the value of Horizontal ranges from 71.5 percent in other transport equipment and 65 percent in electrical equipment and apparatus to 6.6 percent in leather and leather products. The average value increases from almost 12 percent in 1996 to over 31 percent in 2000. Similarly, the value of the Backward variable rises from 3.6 percent in 1996 to 6 percent in 1998 and 8.1 percent in 2000. The highest value is registered in pulp, paper, and paper products (17 percent), basic metals (16.7 percent), and radio, TV, and communications equipment (14.4 percent), while the lowest $(0.2$ percent $)$ is in manufacturing other transport equipment. The Forward proxy ranges from 25.6 percent in manufacturing wearing apparel to 1.65 percent in manufacturing textiles. Again, the Forward variable increases over time, from 3.3 percent in the first year to 13.1 percent in the last year. See Tables 3 and 4 for more details on summary statistics.

Charts 2 through 4 present changes in the value of all spillover variables in each sector between 1996 and 2000. It is worth noting that seven industries registered a rise in the Backward measure of more than 5 percentage points, while a further 10 sectors experienced an increase of more than 2 percentage points. The largest change was observed in textiles, pulp and paper, and wood, as well as rubber and plastics. In the case of the Horizontal variable, the changes were even more pronounced, with 13 industries experiencing an increase of over 10 percentage points, and motor vehicles leading the ranking. Apparel, metal products, and office machinery, on the other hand, saw the greatest change in the Forward measure. 
In an exploratory regression, the model described above is estimated using ordinary least squares (OLS) with White's correction for heteroskedasticity. A firm's output is the dependent variable, and explanatory variables include capital, labor, materials, foreign equity share, and proxies for FDI spillovers operating through horizontal, backward, and forward channels. Since knowledge externalities from the foreign presence may take time to manifest themselves, two specifications are employed: one with contemporaneous and one with lagged spillover variables. The estimation is performed on the full sample and on the sample of domestic firms only. ${ }^{19}$ The model includes fixed effects for years (4), industries (19), and regions (9). The results in Table 5 indicate that firms with foreign capital tend to be more productive than purely Lithuanian firms. And, more important for the purpose of this study, we find a significant and positive coefficient on both Backward and Horizontal variables in all four specifications. The coefficients on lagged values appear be larger and (in the case of Backward) of higher statistical significance. The third spillover variable, Forward, does not appear to be statistically significant. In sum, the results are consistent with productivity spillovers from FDI both taking place within industries and flowing from multinational customers to their domestic suppliers.

To be more confident about isolating the effects of productivity spillovers, we must control for other factors that may influence firm productivity. If multinational entry decreases industry concentration, leading to more competition and forcing domestic firms to improve their efficiency, this situation may still be regarded as a broadly defined spillover effect. Since, however, our interest is primarily knowledge transfer, it would be useful to separate the two phenomena. Thus, the Herfindahl index $(H 4)$ is included as a proxy for the level of industry concentration. ${ }^{20}$ Further, foreign entry into downstream sectors may increase demand for intermediate products which in turn will allow local suppliers to reap the benefits of scale economies. To separate this effect, the regression includes the demand for intermediates calculated based on information on sourcing patterns from the input-output (IO) matrix and the

\footnotetext{
${ }^{19}$ Domestic firms are defined as those with less than 10 percent foreign equity.

${ }^{20}$ The index is defined as the sum of the squared market shares of the four largest producers in a given sector, and its value may range from 0 to 10,000. As pointed out by Nickell (1996), predictions of the theoretical literature on the impact of competition on productivity are ambiguous. In his empirical analysis, however, he finds evidence of competition being positively correlated with productivity growth.
} 
value of production in using sectors. ${ }^{21}$ A positive correlation between demand for intermediates (Demand) and firm productivity is anticipated.

Several econometric concerns need to be addressed in the analysis. The first is the omission of unobserved variables. There may exist firm-, time-, and region-specific factors unknown to the econometrician but known to the firm that may affect the correlation between firm productivity and foreign presence. Examples of these variables include high-quality management in a particular firm or better infrastructure in a given region. This problem is addressed by following Haskel, Pereira, and Slaughter (2002) and using time differencing as well as a full set of fixed effects for year, industry, and region. In addition to removing any fixed firm-specific unobservable variation, differencing will remove fixed regional and industrial effects, such as infrastructure and technological opportunity. Time, industry, and regional dummy variables, on the other hand, will control for unobservables that may be driving changes in, for instance, attractiveness of a particular region or industry. ${ }^{22}$ Thus the specification becomes $\Delta \ln Y_{i j r t}=\delta_{1} \Delta \ln K_{i j r t}+\delta_{2} \Delta \ln L_{i j r t}+\delta_{3} \Delta \ln M_{i j r t}+\delta_{4} \Delta$ Foreign Share $_{i j r t}+\delta_{5} \Delta$ Horizontal $_{j t}+$ $\delta_{6} \Delta$ Backward $_{j t}+\delta_{7} \Delta$ Forward $_{j t}+\delta_{8} \Delta H 4_{j t}+\delta_{9} \Delta \ln$ Demand $_{j t}+\alpha_{t}+\alpha_{r}+\alpha_{j}+\varepsilon_{i j r t}$

The above model is estimated in first, second, and fourth differences. The examination of longer differences gives relatively more weight to more persistent changes in the variables of interest and hence reduces the influence of noise. Its disadvantage is that longer time differences reduce the size of the sample. As a compromise, the above-mentioned sets of differences are employed but only the relationship between contemporaneous changes in FDI and firm level total factor productivity is considered, because adding lags would seriously strain the time span of the data set.

Second, Moulton (1990) showed that in the case of regressions performed on micro units yet including aggregated market (or in this case industry) variables, the standard errors from OLS will be underestimated. As Moulton demonstrated, failing to take this into account leads to a serious downward bias in the estimated errors, resulting in spurious findings of statistical

\footnotetext{
${ }^{21}$ More precisely, Demand $d_{j t}=\Sigma_{k} a_{j k} * Y_{k t}$ where $a_{j k}$ is the IO matrix coefficient indicating that in order to produce one unit of good $k a_{j k}$ units of good $j$ are needed. $Y_{k t}$ stands for industry k output deflated by an industry-specific deflator.
} 
significance for the aggregate variable of interest. To address this issue, the standard errors are corrected for a correlation between observations belonging to the same industry in a given year (in other words, standard errors are clustered for all observations in the same industry and year).

Finally, it has been argued that the use of OLS is inappropriate when estimating productivity, since this method treats labor and other inputs as exogenous variables. Griliches and Mairesse (1995) have made a case that inputs should be considered endogenous since they are chosen by firm based on its productivity, which is observed by the producer but not by the econometrician. Not taking into account the endogeneity of input choices may bias the estimated coefficients. Since the focus of this paper is on firm productivity, the consistency of the estimates is crucial for the analysis.

Therefore, we employ the semiparametric estimation procedure suggested by Olley and Pakes (1996), which allows for firm-specific productivity difference exhibiting idiosyncratic changes over time. Following Olley and Pakes, it is assumed that at the beginning of every period a firm chooses variable factors and a level of investment, which together with the current capital value determine the capital stock at the beginning of the next period. The capital accumulation equation is given by

$k_{i t+1}=(1-\delta) k_{i t}+i_{i t}$

where $k$ stands for capital, $i$ for investment, and $\delta$ for the rate of depreciation.

Consider the following Cobb-Douglas production function model:

$y_{i t}=\alpha+\beta_{l} * l_{i t}+\beta_{k} * k_{i t}+\beta_{m} * m_{i t}+\omega_{i t}+\eta_{i t}$

where $y_{i t}, l_{i t}$, and $m_{i t}$ denote the logarithm of output, labor, and material inputs, respectively, and subscripts $i$ and $t$ stand for firm and time. $\omega_{i t}$ denotes productivity, and $\eta_{i t}$ stands for either measurement error or a shock to productivity that is not forecastable during the period in which labor can be adjusted. Both $\omega_{i t}$ and $\eta_{i t}$ are unobserved. The difference is that $\omega_{i t}$ is a state variable in the firm's decision problem and thus affects the input demand, while $\eta_{i t}$ does not. Labor and materials are assumed to be freely variable inputs. Capital is a fixed factor and is affected only by the distribution of $\omega$ conditional on information at time $t-1$ and past values of $\omega$. The fact

\footnotetext{
${ }^{22}$ In this case the fixed effect for region $r$ captures not just the fact that region $r$ is an attractive business location but also the fact that its attractiveness is changing over time.
} 
that input choices are determined in part by the firm's beliefs about $\omega_{i t}$ gives rise to simultaneity bias. The positive correlation between $\omega_{i t}$ and inputs used in period $t$ will cause an OLS estimation that does not take into account unobserved productivity differences to provide upwardly biased estimates of the coefficients on variable inputs.

The insight of the Olley-Pakes method is that the observable characteristics of the firm can be modeled as a monotonic function of the productivity of the firm. Since the investment decision depends on the capital stock and on firm productivity,

$i_{i t}=i_{i t}\left(\omega_{i t} k_{i t}\right)$

by inverting the above equation, one can express unobserved productivity $\omega_{i t}$ as a function of observable investment and capital and thus control for $\omega_{i t}$ in estimation ${ }^{23}$

$\omega_{i t}=h_{i t}\left(i_{i t,} k_{i t}\right)$

By substituting (4) into (2), the equation to be estimated in the first stage of the procedure is obtained:

$y_{i t}=\alpha+\beta_{l} * l_{i t}+\beta_{k} * k_{i t}+\beta_{m} * m_{i t}+h\left(i_{i t}, k_{i t}\right)+\eta_{i t}$

The functional form of $h($.$) is not known. Therefore, the \beta_{k}$ coefficient cannot be estimated at this stage. A partially linear model including a third-order polynomial expansion in capital and investment to approximate the form of the $h($.$) is estimated. From this stage, the consistent$ estimates of the coefficients on labor and material inputs as well as the estimate of the third-order polynomial in $i_{i t}$ and $k_{i t}$ (referred to as $\psi_{\mathrm{it}}$ ) are obtained.

$\psi_{i t}=\alpha+\beta_{k} * k_{i t}+h\left(i_{i t}, k_{i t}\right)$

Thus,

$h\left(i_{i t}, k_{i t}\right)=\psi_{i t}-\beta_{k} * k_{i t}$

\footnotetext{
${ }^{23}$ Provided that $i_{i t}>0$, it is possible to show that investment is strictly increasing in $\omega_{i t}$ and thus (3) can be inverted.
} 
The second step of the estimation procedure considers the expectation of $y_{i t+1}-\beta_{m} * m_{i t+1}-\beta_{l} * l_{i t+1}$

$$
\begin{aligned}
E\left[y_{i t+1}\right. & \left.-\beta_{m} * m_{i t+1}-\beta_{l} * l_{i t+1} \mid k_{i t+1}\right] \\
& =\alpha+\beta_{k} * k_{i t+1}+E\left[\omega_{i t+1} \mid \omega_{i t}\right] \\
& =\beta_{k} * k_{i t+1}+g\left(\omega_{i t}\right)
\end{aligned}
$$

Assuming that $\omega_{i t}$ follows a first-order Markov process, one can rewrite $\omega_{i t+1}$ as a function of $\omega_{i t}$, letting $\xi_{i t+1}$ be the innovation in $\omega_{i t+1}$. Using (4) and (7), equation (8) becomes a function of $i_{i t}$ and $k_{i t}$

$y_{i t+1}-\beta_{m} * m_{i t+1}-\beta_{l} * l_{i t+1}=\beta_{k} * k_{i t+1}+g\left(\psi_{i t}-\beta_{k} * k_{i t}\right)+\xi_{i t+1}+\eta_{i t+1}$

where $g$ is a third-order polynomial of $\psi_{i t}-\beta_{k} * k_{i t}$. This is the equation to be estimated in the second stage of the procedure. Only in this stage it is possible to obtain consistent estimates of $\beta_{k}$. Since the capital in use in a given period is assumed to be known at the beginning of the period and $\xi_{i t+1}$ is mean independent of all variables known at the beginning of the period, $\xi_{i t+1}$ is mean independent of $k_{i t+1}$. A nonlinear least squares method is used to estimate the above equation.

A production function with the Olley-Pakes correction is estimated for each industry separately. From the estimation, the measure of total factor productivity, which is the difference between the actual and predicted output

$t f p_{i t}=y_{i t}-\beta_{l} * l_{i t}-\beta_{k} * k_{i t}-\beta_{m} * m_{i t}$

is recovered and used in the estimation of the basic model. ${ }^{24}$

The Olley-Pakes correction appears to be working quite well. If the procedure successfully corrects for biases, one would expect to find a decrease in coefficients on labor and material inputs and an increase in the capital coefficient relative to the OLS results. Table 6 presents a comparison of the estimation results from both methods. The material and labor coefficients move in the predicted direction in 17 cases each, while the magnitude of the capital coefficient increases in 16 of 20 cases.

\footnotetext{
${ }^{24}$ While the Olley-Pakes method also allows for controlling for firm exit, this option is not utilized here since, unfortunately, the data set does not allow for distinguishing between firm exit from the sample due to liquidation and firm exit due to not being included in the group of enterprises surveyed in a given year.
} 


\section{Estimation Results from a Model in Differences}

\section{A. Baseline Specification}

A model estimated in first differences produces findings consistent with domestic firms benefiting from the foreign presence in sectors they supply. The first two columns of Table 7 contain the results for the full sample and the subsample of domestic firms, respectively. Owing to space constraints, the coefficients on inputs are not reported. In both regressions, a positive and significant coefficient on the proxy for spillovers through backward linkages can be found. The third and fourth columns present the results from the regressions with the Olley-Pakes correction. $^{25}$ Again the estimations produce a positive and significant coefficient on the Backward variable in both the full sample and the subsample of domestic firms. The size of the coefficients is similar across columns and is slightly larger in the case of the full sample. The magnitude of the effect is economically meaningful. A one-standard-deviation increase in the foreign presence in the sourcing sectors (that is, an increase of 4 percentage points in the backward variable) is associated with a 15 percent rise in output of each domestic firm in the supplying industry. ${ }^{26}$

There is little evidence of spillovers taking place through the other channels. The coefficient on the Horizontal variable does not appear to be statistically significant, which is consistent with the existing literature that fails to find a positive intra-industry effect in developing countries (for example, Aitken and Harrison 1999, Djankov and Hoekman 2000). The Forward variable, on the other hand, bears a negative sign but appears to be statistically significant in only two regressions.

As for the other control variables, there is no indication of a positive association between changes in foreign equity share and productivity growth. Similar to Aitken and Harrison (1999), the results indicate that Foreign Share is positively correlated with productivity levels (recall the results from Table 5) but not with growth rates, suggesting that foreign firms may be investing in

\footnotetext{
${ }^{25}$ The number of observations is lower in these regressions, as the Olley-Pakes procedure can be applied only to firms reporting positive gross investment in a given year.

${ }^{26}$ The calculation is based on the coefficient from the regression with the Olley-Pakes correction estimated on the subsample of domestic firms (column 4).
} 
the most productive domestic enterprises. ${ }^{27}$ Further, a positive coefficient is found on the demand in downstream sectors, indicating the existence of pro-cyclical productivity effects. Finally, the data suggest a positive correlation between industry concentration and productivity growth, but the results are statistically significant in only two cases. ${ }^{28}$

To check the robustness of the results, a model in second and fourth differences is estimated next. Since the sample covers only five years of data, the latter is the longest difference that can be employed. A positive and significant coefficient on the Backward variable is found in all specifications, which again constitutes evidence consistent with productivity spillovers taking place through contacts between domestic firms and their foreign customers in downstream sectors. There is no indication of the other type of vertical spillovers, as the Forward variable appears to be insignificant in the majority of cases. As for intra-sectoral spillovers, only the results on the long differences suggest their existence. These results should, however, be treated with caution as they are based on a small number of observations. The reduction in the sample size may also be responsible for the change in the sign of demand from downstream sectors, which, in the fourth difference specification, appears to be negatively correlated with firm productivity. $^{29}$

\section{B. Full versus Partial Foreign Ownership}

Next consider the hypothesis that backward linkages associated with partially owned foreign projects lead to greater spillovers than linkages associated with wholly owned foreign affiliates because of different propensities to engage in local sourcing. To examine this question, two measures of backward linkages are calculated for the two types of foreign investments. The proxy for fully owned foreign projects is defined as

\footnotetext{
${ }^{27}$ This conclusion is supported by the findings from transition economies obtained by Djankov and Hoekman (2000) and Evenett and Voicu (2001). Note that Aitken and Harrison (1999) also report a similar pattern of results in their analysis of Indonesian data (p. 617, footnote 12).

As an additional check, we experimented with including an indicator variable for the cases when the foreign share increases from under 50 percent to above 50 percent (thus giving the foreign investor majority ownership), but it did not appear to be statistically significant.

${ }^{28}$ This finding would be consistent with Schumpeterian-style argument that more monopolistic firms can more readily fund research and development expenditure because they face less market uncertainty and have a larger and more stable cash flow (see Levin, Cohen, and Mowery 1985).

${ }^{29}$ Note that this change is not due to multicolinearity with the Backward variable, as the correlation between the two is 0.3 .
} 


$$
\begin{gathered}
\text { Backward }(\text { Full Ownership })_{j t}= \\
\Sigma_{k \text { if } k \neq j} \alpha_{j k} *\left[\Sigma_{\text {ifor all } i \in k} \operatorname{WOS}_{i t} * \text { Foreign Share }_{i t} * Y_{i t}\right] / \Sigma_{\text {ifor all } i \in k} Y_{i t}
\end{gathered}
$$

where WOS is a dummy for wholly owned subsidiaries. It is equal to one for firms with the share of foreign capital equal to at least 99 percent. $^{30}$ The measure for partially owned investments (those with foreign capital participation above 10 but below 99 percent) is defined in an analogous manner.

The results shown in Table 8 support the hypothesis. A significant and positive correlation is found between changes in output of domestic firms and backward linkages associated with partially foreign-owned projects but not wholly foreign-owned affiliates. The difference between the magnitudes of the two coefficients is statistically significant in three out of four cases (in the case of the full sample, at the 1 percent level). These findings are consistent with the observation that projects owned jointly by domestic and foreign entities are more likely to source locally, thus creating greater scope for spillovers to firms operating in upstream sectors.

The other variables exhibit patterns similar to those observed in the previous table. The only exception is the Forward measure, which appears to be negative and statistically significant in three out of four cases, suggesting that foreign presence in upstream sectors has a negative impact on the performance of local firms in using industries. This finding is similar to that obtained by Schoors and van der Tol (2001). A possible explanation is that after buying out domestic firms in supplying sectors, foreign owners upgrade production facilities and manufacture more sophisticated products that are then sold at a higher price. Local firms in using sectors that purchase these inputs may have limited ability to benefit from their higher technological content but are forced to bear the higher cost.

Another reason why the extent of foreign ownership may matter for spillovers is the control over company operations. For instance, foreign owners may be more inclined to import intermediate inputs (for example, due to their familiarity with foreign suppliers) but may be in better position to do so in enterprises where they have majority ownership. Thus, as a robustness check, a model comparing the effect of minority- versus majority-owned foreign investments on spillovers through backward linkages was estimated. Since no significant difference between vertical spillovers from the two types of projects was found, the results are not reported here. 
To conclude, the findings are consistent with the observation that domestic capital participation in FDI projects lowers foreign investors' costs of using local suppliers and thus results in more local sourcing and greater productivity spillovers to domestic producers of intermediate inputs.

\section{Robustness Checks}

This section describes three additional extensions and robustness checks. First, it is conceivable, though not very likely, that the results on the effect of backward linkages are driven by the level of concentration in purchasing industries (which may be correlated with foreign presence) rather than genuine knowledge spillovers from FDI. For instance, both domestic and foreign enterprises operating in concentrated sectors may have more resources to provide assistance to their suppliers, although at the same time may be less inclined to do so. On the other hand, firms in competitive industries may have fewer resources to support their suppliers but may have a greater incentive to transfer knowledge to downstream sectors in order to obtain higher quality or less expensive inputs. Thus, ex ante, the effect of concentration is ambiguous.

To eliminate the alternative explanation driven by the above arguments, a model is estimated testing whether a differential effect of foreign presence in the two types of downstream industries exists. The U.S. Department of Justice definition of concentrated sectors (those with the Herfindahl index for the largest four firms exceeding 1,800) is employed to calculate separate measures of Backward for concentrated and competitive industries. ${ }^{31}$ The results, presented in Table 9, indicate, that foreign presence in both types of upstream industries leads to positive spillovers to supplying sectors. The Backward variable is statistically significant seven out of eight times - the only exception being the case of spillovers from concentrated industries in the regression with the Olley-Pakes correction estimated on the subsample of domestic firms. In all four models, there is no statistically significant difference between the magnitude of the

\footnotetext{
${ }^{30}$ There are 342 observations pertaining to fully owned foreign affiliates and a further 35 observations for firms with foreign capital share between 99 and 100 percent. Together they constitute 27 percent of all observations pertaining to firms with foreign capital participation.

${ }^{31}$ The following seven sectors fall into the concentrated category: NACE 24 (chemicals and chemical products), NACE 27 (basic metals), NACE 30 (office machinery and computers), NACE 31 (electrical equipment and apparatus), NACE 32 (radio, TV and communications equipment), NACE 34 (motor vehicles), and NACE 35 (other transport equipment).
} 
backward linkage effect for the two types of sectors, suggesting that the level of concentration in upstream sectors is not a concern in the model.

Second, the motivation for undertaking FDI is likely to affect the extent of local sourcing by foreign subsidiaries. It has been suggested that domestic-market-oriented foreign affiliates tend to purchase more inputs locally than their export-oriented counterparts (Altenburg 2000, UNCTC 2000). Exporting affiliates that are part of international production networks are more likely to be dependent on the global sourcing policies of their parent company and thus may have less freedom to choose their own suppliers. Moreover, quality and technical requirements associated with goods targeted for the domestic market may be lower, so local suppliers may find it easier to serve multinationals focused on the domestic market. On the other hand, if multinationals serving global markets impose more stringent cost and quality requirements and thus necessitate greater adjustments and larger productivity improvements on the part of local suppliers, one may expect more spillovers to be associated with exporting multinationals. This effect would be reinforced by the fact that multinationals serving global markets may possess superior technologies, creating greater opportunities for learning by local suppliers. In summary, the theoretical predictions regarding the relationship between export orientation of multinationals and spillovers are ambiguous.

To examine whether the export orientation of foreign affiliates matters for spillovers, two separate measures of backward linkages are calculated: one for affiliates focused mostly on exporting and one for foreign firms targeting the domestic market. The former variable is defined as follows:

$$
\begin{gathered}
\text { Backward }(\text { Export-Oriented })_{j t}= \\
\Sigma_{k i f k \neq j} \alpha_{j k} *\left[\Sigma_{\text {ifor all } i \in k} \text { Export-Oriented }_{i t} * \text { Foreign Share }_{i t} * Y_{i t}\right] / \Sigma_{\text {ifor all } i \in k} Y_{i t}
\end{gathered}
$$

where Export-Oriented $d_{i t}$ is equal to one if the share of output exported by firm $i$ is above 50 percent and zero otherwise. The measure for domestic-market-oriented foreign affiliates is defined analogously. The results (not reported here) suggest that both types of foreign affiliates are associated with spillovers to upstream sectors. While the magnitude of the coefficient on domestic-market-oriented affiliates is larger in three out of four cases, the difference between the two coefficients is not statistically significant. The same exercise was performed for two additional cutoff points, 66 and 90 percent of output exported, but only in regressions estimated 
with the Olley-Pakes correction on the subsample of domestic firms was the coefficient on Backward (Domestic-Market-Oriented) significantly larger than the coefficient on the measure of spillovers associated with exporting affiliates. Thus, there is some indication of domesticmarket-oriented FDI projects being correlated with greater productivity spillovers to their local suppliers, but the evidence is not very robust.

Finally, to correct for potential biases in coefficients on variable factor inputs, the share of foreign capital as well as other sectoral variables (Horizontal, Backward, Forward, H4, and Demand) was included in the first stage of the Olley-Pakes procedure. Thus, for each of the exercises presented in Tables 7 through 9, a separate Olley-Pakes procedure with the relevant spillover measures added to the first stage was estimated. The results from this estimation, however, led to exactly the same conclusions as those presented here, and are, therefore, not included in the paper. A likely reason why this modification did not produce significant changes to the results is that investment, which enters the first stage of the Olley-Pakes procedure in the polynomial form, picks up most of the effect foreign entry and presence have on firm behavior.

\section{Conclusions}

In contrast to earlier literature, which focused on intra-industry spillovers from FDI, this study tests for productivity spillovers taking place through backward linkages (contacts between foreign affiliates and their domestic suppliers) and forward linkages (interactions between foreign suppliers of intermediate inputs and their domestic customers). The analysis, based on a firm-level panel data set from Lithuania, addresses econometric issues that may have biased the findings of earlier research, such as endogeneity of input demand and correction of standard errors, to account for the fact that while observations pertain to firms, the variables of interest are at the industry level.

The results are consistent with the presence of productivity spillovers taking place through backward linkages. They suggest that a one-standard-deviation increase in the foreign presence in downstream sectors is associated with a 15 percent rise in output of each domestic

firm in supplying industries. Productivity benefits are found to be associated with partially but not fully owned foreign projects, which is in line with the evidence suggesting a larger extent of 
local sourcing undertaken by the former type of FDI. Finally, as was the case with the earlier firm-level studies of developing countries, no evidence of intra-sectoral spillovers is found. Nor is there any indication of spillovers stemming from multinational presence in sectors supplying intermediate inputs.

Certainly more research is needed to fully understand the effect of FDI on host countries. In particular, it would be useful to confirm the findings of this paper using data that allow for identification of individual firms as suppliers to multinationals rather than relying on inputoutput matrices to measure interactions between sectors. Moreover, it would be interesting to learn more about host country and investor characteristics that determine the extent of spillovers operating through different channels. It is to be hoped that improved data availability will allow researchers to examine these questions in the future. 


\section{References}

Aitken, Brian J., and Ann E. Harrison. 1999. "Do Domestic Firms Benefit from Direct Foreign Investment? Evidence from Venezuela." American Economic Review 89(3): 605-618.

Aitken, Brian, Ann E. Harrison, and Robert Lipsey. 1997. "Wages and Foreign Ownership: A Comparative Study of Mexico, Venezuela and the United States." Journal of International Economics 40: 345-371.

Altenburg, Tilman. 2000. "Linkages and Spillovers between Transnational Corporations and Small and Medium-sized Enterprises in Developing Countries: Opportunities and Best Policies." In UNCTAD, ed., TNC-SME Linkages for Development: Issues-ExperiencesBest Practices. New York and Geneva: United Nations.

Belderbos, Rene, Giovanni Capannelli, and Kyoji Fukao. 2001. "Backward Vertical Linkages of Foreign Manufacturing Affiliates: Evidence from Japanese Multinationals." World Development 29(1): 189-208.

Belkindas, Misha, Mustafa Dinc, and Olga Ivanova. 1999. "Statistical Systems Need Overhaul in Transition Economies." Transition 10(4): 22-24.

Blalock, Garrick. 2001. "Technology from Foreign Direct Investment: Strategic Transfer through Supply Chains." Mimeo, Haas School of Business, University of California, Berkeley.

Blomström, Magnus. 1986. "Foreign Investment and Productive Efficiency: The Case of Mexico." Journal of Industrial Economics 35(1): 97-110.

Blomström, Magnus. 1989. Foreign Investment and Spillovers. London: Routledge.

Blomström, Magnus, and Ari Kokko. 1998. "Multinational Corporations and Spillovers." Journal of Economic Surveys 12(2): 1-31.

Blomström, Magnus, and Hakan Persson. 1983. "Foreign Investment and Spillover Efficiency in an Underdeveloped Economy: Evidence from the Mexican Manufacturing Industry." World Development 11(6): 493-501.

Blomström, Magnus, and Edward W. Wolff. 1994. "Multinational Corporations and Productivity Convergence in Mexico." In W. Baumol, R. Nelson, and E. Wolff, eds., Convergence of Productivity: Cross-national Studies and Historical Evidence. Oxford: Oxford University Press.

Blomström, Magnus, Ari Kokko, and Mario Zejan. 2000. Foreign Direct Investment: Firm and Host Country Strategies. London: Macmillan Press.

Caves, Richard E. 1974. "Multinational Firms, Competition and Productivity in Host-Country Markets.” Economica 41(162):176-193.

Djankov, Simeon, and Bernard Hoekman. 2000. "Foreign Investment and Productivity Growth in Czech Enterprises." World Bank Economic Review 14(1):49-64.

European Bank for Reconstruction and Development (EBRD). 2001. Lithuania Investment Profile 2001. London. 
Evenett, Simon J., and Alexandru Voicu. 2001. "Picking Winners or Creating Them? Revisiting the Benefits of FDI in the Czech Republic?" Mimeo, the World Bank.

Foreign Investment Advisory Service (FIAS). 2003. "Developing Knowledge Intensive Sectors, Technology Transfers, and the Role of FDI." Mimeo, the World Bank, Washington, DC.

Girma, Sourafel, David Greenaway, and Katharine Wakelin. 2001. "Who Benefits from Foreign Direct Investment in the UK?" Scottish Journal of Political Economy 48:119-133.

Görg, Holger, and Eric Strobl. 2001. "Multinational Companies and Productivity Spillovers: A Meta-Analysis." The Economic Journal 111:723-739.

Griliches, Z., and J. Mairesse. 1995. "Production Functions: the Search for Identification." NBER Working Paper 5067. Cambridge, MA: National Bureau of Economic Research.

Griliches, Z., and V. Ringstad. 1971. Economies of Scale and the Form of the Production Function. Amsterdam: North-Holland.

Haddad, Mona, and Ann E. Harrison. 1993. "Are There Positive Spillovers from Direct Foreign Investment? Evidence from Panel Data for Morocco." Journal of Development Economics 42: 51-74.

Haskel, Jonathan E., Sonia C. Pereira, and Matthew J. Slaughter. 2002. "Does Inward Foreign Direct Investment Boost the Productivity of Domestic Firms?" NBER Working Paper 8724. Cambridge, MA: National Bureau of Economic Research.

Javorcik, Beata Smarzynska.(forthcoming). "The Composition of Foreign Direct Investment and Protection of Intellectual Property Rights: Evidence from Transition Economies." European Economic Review.

Keller, Wolfgang, and Stephen Yeaple. 2003. "Multinational Enterprises, International Trade and Productivity Growth: Firm Level Evidence from the United States." NBER Working Paper 9504. Cambridge, MA: National Bureau of Economic Research.

Kugler, Maurice. 2000. "The Diffusion of Externalities from Foreign Direct Investment: Theory Ahead of Measurement." Discussion Papers in Economics and Econometrics, University of Southampton, UK.

Levin, Richard, Wesley Cohen, and David Mowery. 1985. "R\&D Appropriability, Opportunity, and Market Structure: New Evidence on Some Schumpeterian Hypotheses." AER Papers and Proceedings 75:20-24.

Lipsey, Robert E. 2002. "Home and Host Country Effects of FDI." NBER Working Paper 9293 . Cambridge, MA: National Bureau of Economic Research.

Liu, X., P. Siler, C. Wang, and Y. Wei. 2000. "Productivity Spillovers from Foreign Direct Investment: Evidence from UK Industry Level Panel Data.” Journal of International Business Studies 31:407-425.

Markusen, James R., and Anthony J. Venables. 1999. "Foreign direct investment as a catalyst for industrial development." European Economic Review 43:335-356.

Moran, Theodore. 2001. Parental Supervision: The New Paradigm for Foreign Direct Investment and Development. Washington, DC: Institute for International Economics. 
Moulton, Brent R. 1990. "An Illustration of a Pitfall in Estimating the Effects of Aggregate Variables on Micro Units." Review of Economics and Statistics 72(2):334-338.

Nickell, Stephen. 1996. "Competition and Corporate Performance." Journal of Political Economy 104(4):724-746.

Organisation for Economic Co-operation and Development (OECD). 2000. "Lithuania: Foreign Direct Investment Impact and Policy Analysis." Paris.

OECD. 2001. "Reviews of Foreign Direct Investment: Lithuania.” Paris.

Olley, Steven G., and Ariel Pakes. 1996. "The Dynamics of Productivity in the

Telecommunications Equipment Industry." Econometrica 64(6):1263-1297.

Rodriguez-Clare, Andres. 1996. "Multinationals, linkages, and economic development." American Economic Review 86:852-873.

Rodrik, Dani. 1999. “The new global economy and developing countries: Making openness work." Policy Essay No. 24, Overseas Development Council. Baltimore, MD: John Hopkins University Press.

Saggi, Kamal. 2002. "Backward Linkages under Foreign Direct Investment.” Mimeo, Southern Methodist University.

Schoors, Koen, and Bartoldus van der Tol. 2001. "The Productivity Effect of Foreign Ownership on Domestic Firms in Hungary." Mimeo, University of Ghent.

Toth, Istvan Janos, and Andras Semjen. 1999. "Market Links and Growth Capacity of Enterprises in A Transforming Economy: The Case of Hungary.” In Istvan Janos Toth and Andras Semjen, eds., Market Links, Tax Environment and Financial Discipline of Hungarian Enterprises. Budapest: Institute of Economics, Hungarian Academy of Sciences.

Tybout, James, Jaime de Melo, and Vittorio Corbo. 1991. "The effects of trade reforms on scale and technical efficiency." Journal of International Economics 31:231-250.

United Nations Centre on Transnational Corporations (UNCTC). 2000. The Competitiveness Challenge: Transnational Corporations and Industrial Restructuring in Developing Countries. New York and Geneva: United Nations.

UNCTC. 2001. World Investment Report. Promoting Linkages. New York and Geneva: United Nations. 


\section{Appendix}
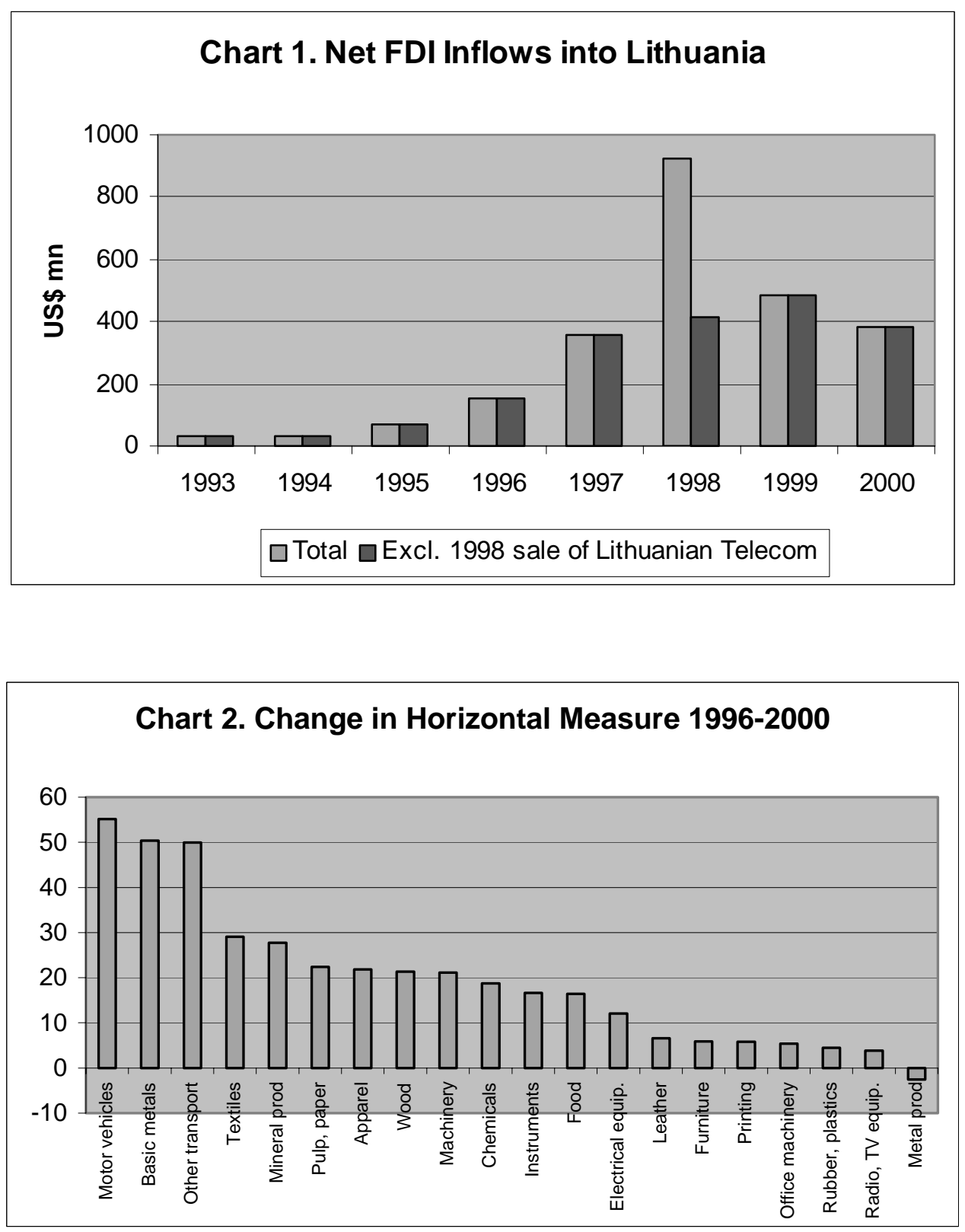

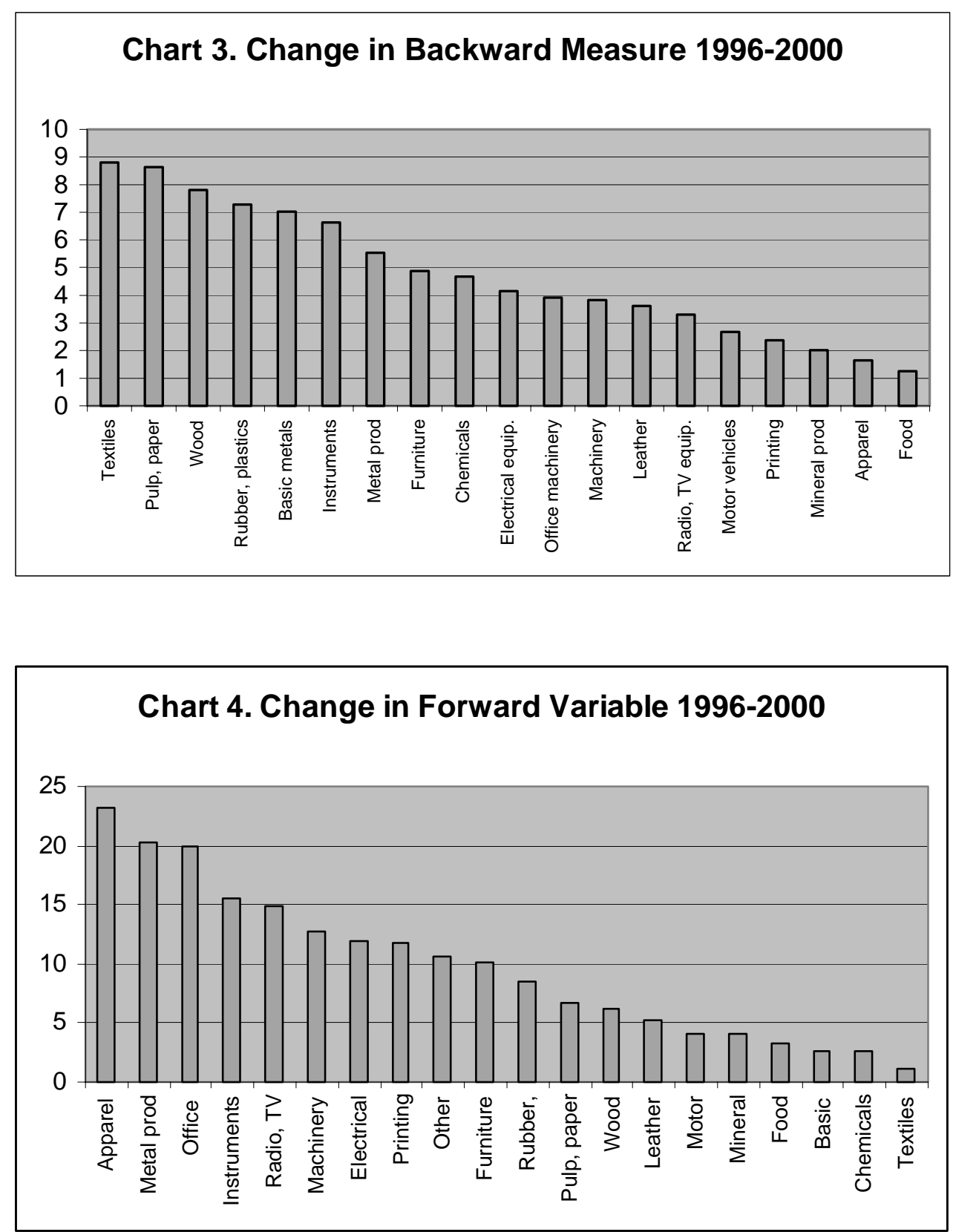
Table 1. FDI Inflows into CEECs, 1993-2000

\begin{tabular}{|c|c|c|c|c|c|c|c|c|c|c|c|c|}
\hline & \multicolumn{8}{|c|}{ FDI inflow (millions of US\$) } & \multicolumn{2}{|c|}{$\begin{array}{c}\text { FDI inflows } \\
2000 \\
\end{array}$} & \multicolumn{2}{|c|}{$\begin{array}{c}\text { FDI inflows } \\
1993-2000\end{array}$} \\
\hline & 1993 & 1994 & 1995 & 1996 & 1997 & 1998 & 1999 & 2000 & $\begin{array}{c}\text { as } \% \text { of } \\
\text { GDP }\end{array}$ & $\begin{array}{c}\text { per capita } \\
\text { (US\$) }\end{array}$ & $\begin{array}{c}\text { Value } \\
\text { (mn US\$) }\end{array}$ & $\begin{array}{l}\text { Per capita } \\
\text { (US\$) }\end{array}$ \\
\hline Czech Republic & 654 & 878 & 2,568 & 1,435 & 1,286 & 3,700 & 6,313 & 4,987 & 9.7 & 485 & 21,822 & 2,124 \\
\hline Hungary & 2,350 & 1,144 & 4,519 & 2,274 & 2,167 & 2,037 & 1,977 & 1,646 & 3.5 & 163 & 18,113 & 1,790 \\
\hline Latvia & 45 & 214 & 180 & 382 & 521 & 357 & 348 & 410 & 5.7 & 173 & 2,456 & 1,036 \\
\hline Poland & 1,715 & 1,875 & 3,659 & 4,498 & 4,908 & 6,365 & 7,270 & 9,341 & 5.9 & 242 & 39,631 & 1,025 \\
\hline Slovak Republic & 199 & 270 & 236 & 351 & 174 & 562 & 354 & 2,052 & 10.4 & 380 & 4,198 & 777 \\
\hline Lithuania & 30 & 31 & 73 & 152 & 355 & 926 & 486 & 379 & 3.4 & 108 & 2,432 & 694 \\
\hline Slovenia & 113 & 117 & 150 & 173 & 334 & 216 & 107 & 136 & 0.7 & 68 & 1,345 & 676 \\
\hline
\end{tabular}

Source: IMF International Financial Statistics (FDI figures) and World Bank World Development Indicators (GDP and population). Note: $\mathrm{CEECs}=$ Central and Eastern European countries; FDI $=$ foreign direct investment. 
Table 2. Distribution of Firms with Foreign Capital by Industry in 2000

\begin{tabular}{|c|c|c|c|c|c|c|c|c|c|}
\hline Code & Sector & $\begin{array}{c}\text { Distribution of } \\
\text { FDI across } \\
\text { Sectors }{ }^{\mathrm{a}}(\%) \\
\end{array}$ & $\begin{array}{c}\text { Domestic } \\
\text { Firms } \\
\text { (1) }\end{array}$ & $\begin{array}{c}\text { Firms with } \\
\text { Foreign } \\
\text { Capital }^{\mathrm{b}}(2) \\
\end{array}$ & $\begin{array}{l}\text { All Firms } \\
\text { (3) }\end{array}$ & $(2) /(3) * 100$ & Horizontal & Backward & Forward \\
\hline 15 & $\begin{array}{l}\text { Food products and } \\
\text { beverages }\end{array}$ & 19.6 & 396 & 50 & 446 & 11.2 & 26.6 & 1.5 & 4.8 \\
\hline 17 & Textiles & 12.5 & 74 & 30 & 104 & 28.8 & 39.7 & 13.7 & 1.7 \\
\hline 18 & Wearing apparel & 1.9 & 172 & 43 & 215 & 20.0 & 33.5 & 2.7 & 25.6 \\
\hline 19 & Leather and leather products & 0.1 & 19 & 3 & 22 & 13.6 & 6.6 & 6.8 & 15.3 \\
\hline 20 & $\begin{array}{l}\text { Wood and wood products, } \\
\text { except furniture }\end{array}$ & 4.2 & 382 & 43 & 425 & 10.1 & 34.3 & 12.5 & 8.4 \\
\hline 21 & $\begin{array}{l}\text { Pulp, paper, and paper } \\
\text { products }\end{array}$ & 2.3 & 17 & 6 & 23 & 26.1 & 39.4 & 17.2 & 10.9 \\
\hline 22 & $\begin{array}{l}\text { Publishing, printing, and } \\
\text { recorded media }\end{array}$ & 0.2 & 204 & 12 & 216 & 5.6 & 7.0 & 3.5 & 18.3 \\
\hline 24 & $\begin{array}{l}\text { Chemicals and chemical } \\
\text { products }\end{array}$ & 10.7 & 44 & 17 & 61 & 27.9 & 20.9 & 7.4 & 3.7 \\
\hline 25 & Rubber and plastic products & 3.8 & 111 & 25 & 136 & 18.4 & 31.4 & 11.0 & 10.9 \\
\hline 26 & $\begin{array}{l}\text { Other nonmetallic mineral } \\
\text { products }\end{array}$ & 7.4 & 141 & 17 & 158 & 10.8 & 35.3 & 3.1 & 6.8 \\
\hline 27 & Basic metals & 0.6 & 6 & 3 & 9 & 33.3 & 50.3 & 16.7 & 4.3 \\
\hline 28 & Fabricated metal products & 0.7 & 156 & 24 & 180 & 13.3 & 10.7 & 8.4 & 22.3 \\
\hline 29 & Machinery and equipment & 1.1 & 94 & 12 & 106 & 11.3 & 23.2 & 6.9 & 15.3 \\
\hline 30 & $\begin{array}{l}\text { Office machinery and } \\
\text { computers }\end{array}$ & 0.0 & 8 & 2 & 10 & 20.0 & 8.0 & 6.3 & 22.5 \\
\hline 31 & $\begin{array}{l}\text { Electrical equipment and } \\
\text { apparatus }\end{array}$ & 1.2 & 37 & 4 & 41 & 9.8 & 65.3 & 7.1 & 15.0 \\
\hline 32 & $\begin{array}{l}\text { Radio, television, and } \\
\text { communication equip. }\end{array}$ & 4.3 & 24 & 5 & 29 & 17.2 & 32.2 & 14.4 & 17.0 \\
\hline 33 & $\begin{array}{l}\text { Medical, precision and } \\
\text { optical instruments }\end{array}$ & 0.8 & 42 & 7 & 49 & 14.3 & 23.8 & 11.9 & 18.7 \\
\hline 34 & Motor vehicles & 0.8 & 9 & 1 & 10 & 10.0 & 59.8 & 4.4 & 12.6 \\
\hline 35 & Other transport equipment & 7.6 & 39 & 8 & 47 & 17.0 & 71.5 & 0.2 & 13.1 \\
\hline 36 & Furniture & 0.6 & 154 & 20 & 174 & 11.5 & 9.7 & 6.9 & 14.5 \\
\hline & Total & 80.4 & 2129 & 332 & 2461 & 13.5 & 31.5 & 8.1 & 13.1 \\
\hline
\end{tabular}

\footnotetext{
${ }^{a}$ Shares do not add up to 100 percent since NACE 16 (tobacco) and NACE 23 (manufacturing of refined petroleum products), which account for 0.9 and 18.7 percent of FDI stock, are not included in the table.

${ }^{\mathrm{b}}$ foreign share of at least 10 percent of total capital.
} 
Table 3. Summary Statistics

\begin{tabular}{lrrrrrr}
\hline & \multicolumn{3}{c}{ Summary Statistics for Levels } & \multicolumn{3}{r}{ Summary Statistics for First Differences } \\
\hline & No. Obs. & \multicolumn{1}{c}{ Mean } & SD & No. Obs. & Mean & SD \\
\hline & & & & & & \\
ln Y & 11,630 & 13.5 & 2.0 & 6,853 & 0.01 & 0.6 \\
$\ln \mathrm{L}$ & 11,630 & 6.1 & 1.8 & 6,853 & -0.06 & 0.6 \\
$\ln$ K & 11,630 & 12.0 & 2.4 & 6,853 & 0.26 & 0.7 \\
ln Materials & 11,630 & 12.3 & 2.5 & 6,853 & -0.02 & 1.1 \\
ln Gross Investment & 8,262 & 10.6 & 2.4 & 3,765 & -0.04 & 1.8 \\
Foreign share & 11,630 & 7.8 & 23.0 & 6,853 & 0.42 & 9.1 \\
Exports share & 9,762 & 21.1 & 34.0 & 5,757 & -1.20 & 22.6 \\
Horizontal & 11,630 & 19.7 & 12.3 & 6,853 & 3.99 & 4.7 \\
Backward & 11,630 & 4.9 & 3.9 & 6,853 & 1.05 & 1.1 \\
Backward (fully foreign owned) & 11,630 & 1.9 & 2.0 & 6,853 & 0.41 & 0.6 \\
Backward (partially foreign owned) & 11,630 & 3.0 & 2.5 & 6,853 & 0.64 & 1.1 \\
Backward (concentrated) & 11,630 & 1.9 & 2.1 & 6,853 & 0.37 & 0.8 \\
Backward (competitive) & 11,630 & 2.9 & 3.0 & 6,853 & 0.68 & 1.1 \\
Forward & 11,630 & 6.9 & 5.5 & 6,853 & 2.38 & 2.6 \\
ln Demand & 11,630 & 18.9 & 1.4 & 6,853 & 0.06 & 0.1 \\
H4 & 11,630 & 576.9 & 844.4 & 6,853 & -8.03 & 209.3 \\
& & & & & & \\
\hline
\end{tabular}

Note: No. Obs. $=$ number of observations; $\mathrm{SD}=$ standard deviation.

Table 4. Additional Summary Statistics for Spillover Variables

\begin{tabular}{cccc|cccc|cccc}
\hline \multicolumn{4}{c}{ Horizontal } & \multicolumn{4}{c|}{ Backward } & \multicolumn{4}{c}{ Forward } \\
\hline Year & Mean & SD & $\begin{array}{c}\text { No. of } \\
\text { Industries }\end{array}$ & Year & Mean & SD & $\begin{array}{c}\text { No. of } \\
\text { Industries }\end{array}$ & Year & Mean & SD & $\begin{array}{c}\text { No. of } \\
\text { Industries }\end{array}$ \\
\hline & & & & & & & & & & & \\
1996 & 11.85 & 12.92 & 20 & 1996 & 3.62 & 3.05 & 20 & 1996 & 3.29 & 2.42 & 20 \\
1997 & 17.32 & 15.70 & 20 & 1997 & 5.17 & 4.03 & 20 & 1997 & 4.27 & 2.83 & 20 \\
1998 & 21.95 & 15.58 & 20 & 1998 & 6.02 & 4.59 & 20 & 1998 & 6.16 & 3.14 & 20 \\
1999 & 28.93 & 19.93 & 20 & 1999 & 7.72 & 4.93 & 20 & 1999 & 8.81 & 4.27 & 20 \\
2000 & 31.46 & 19.20 & 20 & 2000 & 8.13 & 5.00 & 20 & 2000 & 13.08 & 6.70 & 20 \\
& & & & & & & & & & \\
\hline
\end{tabular}


Table 5. OLS with Lagged and Contemporaneous Spillover Variables

\begin{tabular}{|c|c|c|c|c|}
\hline & All Firms & Domestic & All Firms & Domestic \\
\hline Foreign share & $\begin{array}{r}0.0025 * * * * \\
(0.0002)\end{array}$ & & $\begin{array}{r}0.0025 * * * * \\
(0.0003)\end{array}$ & \\
\hline Backward & $\begin{array}{r}0.0105 * * \\
(0.0048)\end{array}$ & $\begin{array}{c}0.0086 * \\
(0.0051)\end{array}$ & & \\
\hline Backward lagged & & & $\begin{array}{r}0.0173 * * * \\
(0.0060)\end{array}$ & $\begin{array}{r}0.0177 * * * \\
(0.0066)\end{array}$ \\
\hline Forward & $\begin{array}{l}-0.0030 \\
(0.0024)\end{array}$ & $\begin{array}{r}0.0001 \\
(0.0027)\end{array}$ & & \\
\hline Forward lagged & & & $\begin{array}{l}-0.0029 \\
(0.0040)\end{array}$ & $\begin{array}{l}-0.0007 \\
(0.0044)\end{array}$ \\
\hline Horizontal & $\begin{array}{r}0.0029 * * \\
(0.0013)\end{array}$ & $\begin{array}{r}0.0040^{* * * *} \\
(0.0014)\end{array}$ & & \\
\hline Horizontal lagged & & & $\begin{array}{l}\text { 0.0038* } \\
(0.0021)\end{array}$ & $\begin{array}{r}0.0046 * * \\
(0.0023)\end{array}$ \\
\hline Intercept & $\begin{array}{r}5.2323^{* * * *} \\
(0.0805)\end{array}$ & $\begin{array}{r}5.2082^{* * * *} \\
(0.0876)\end{array}$ & $\begin{array}{r}5.1599 * * * \\
(0.1007)\end{array}$ & $\begin{array}{r}5.1582 * * * \\
(0.1108)\end{array}$ \\
\hline No. of obs. & 11,630 & 10,216 & 8,214 & 7,118 \\
\hline R-squared & 0.93 & 0.92 & 0.93 & 0.92 \\
\hline
\end{tabular}




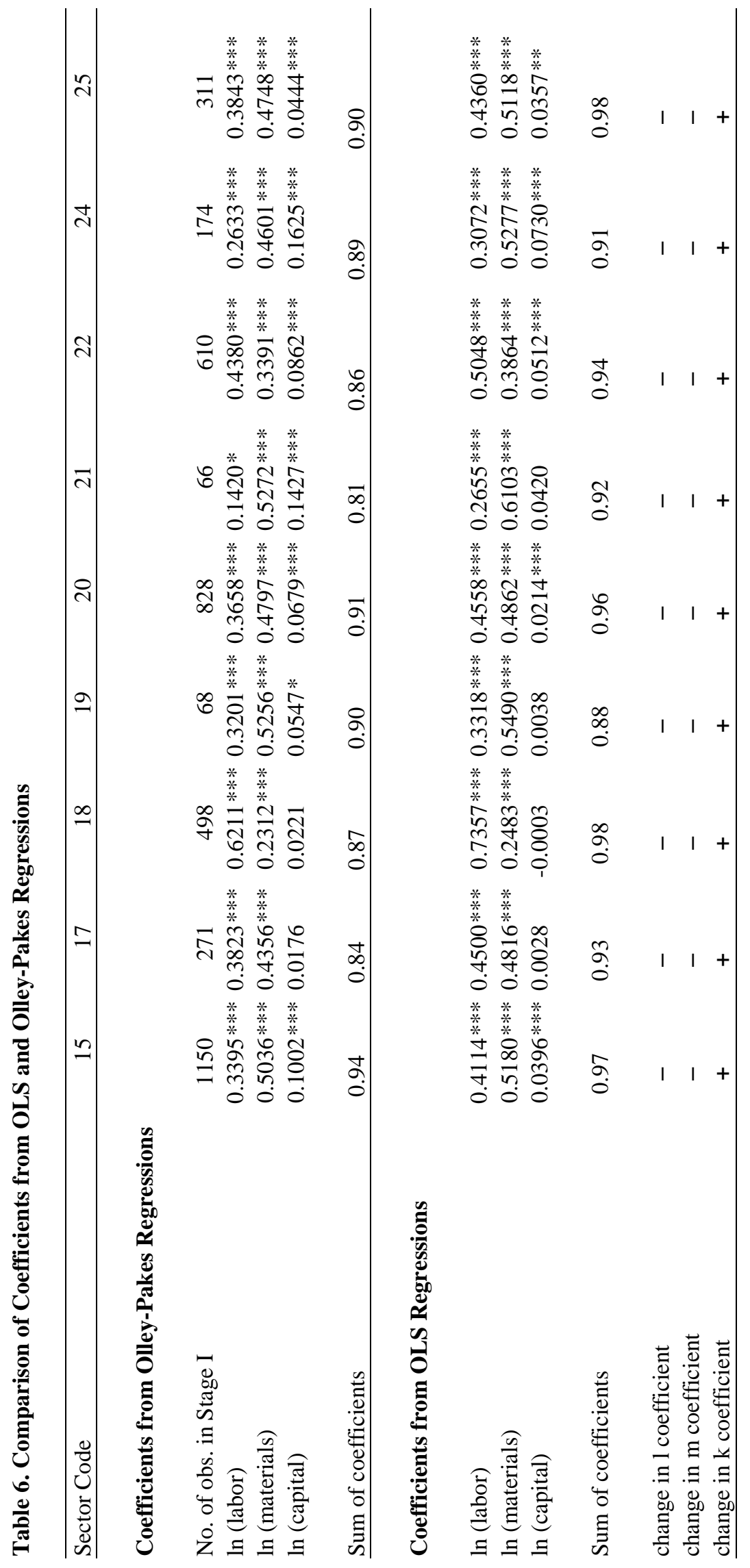

$m$ 


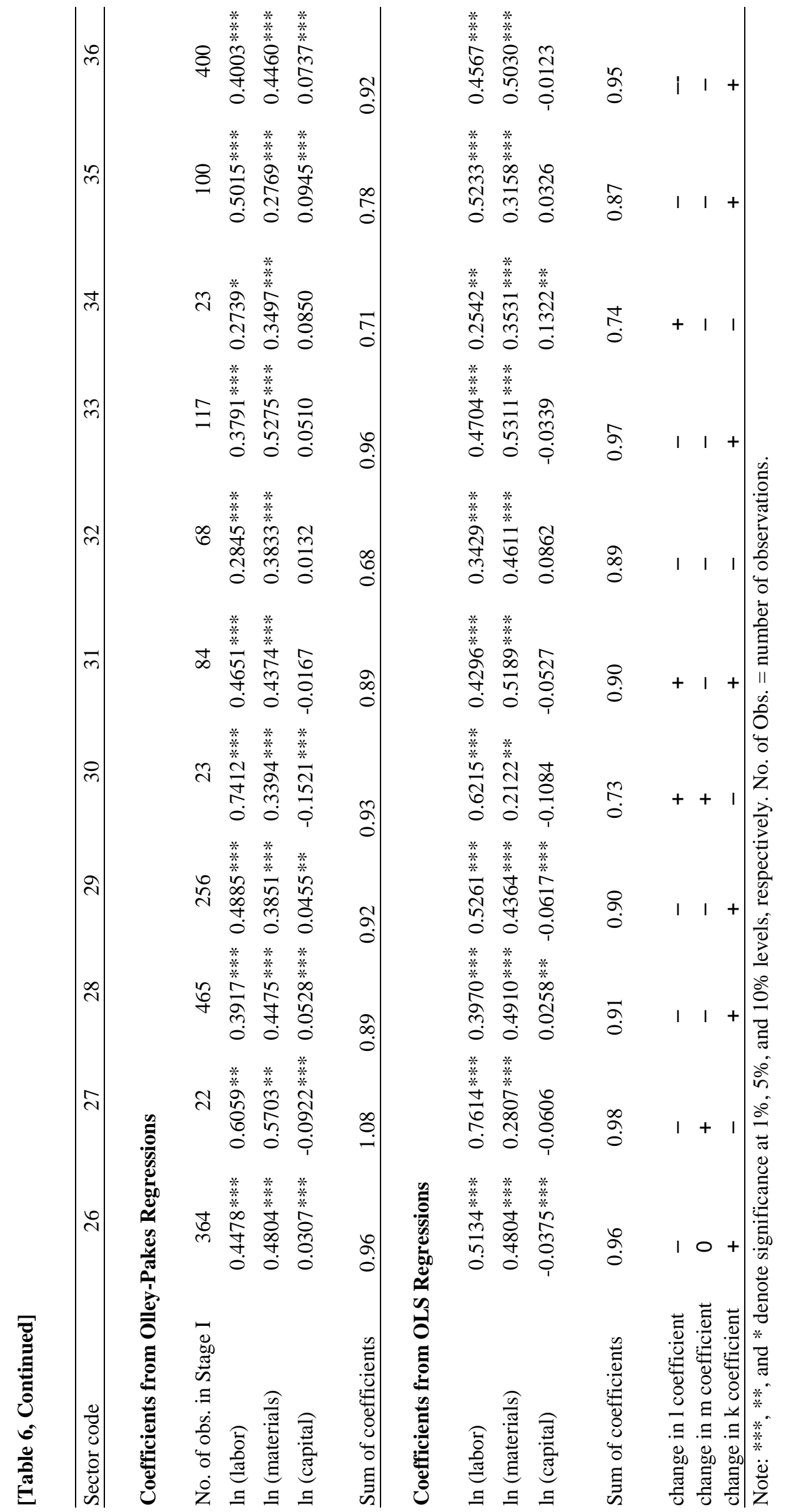




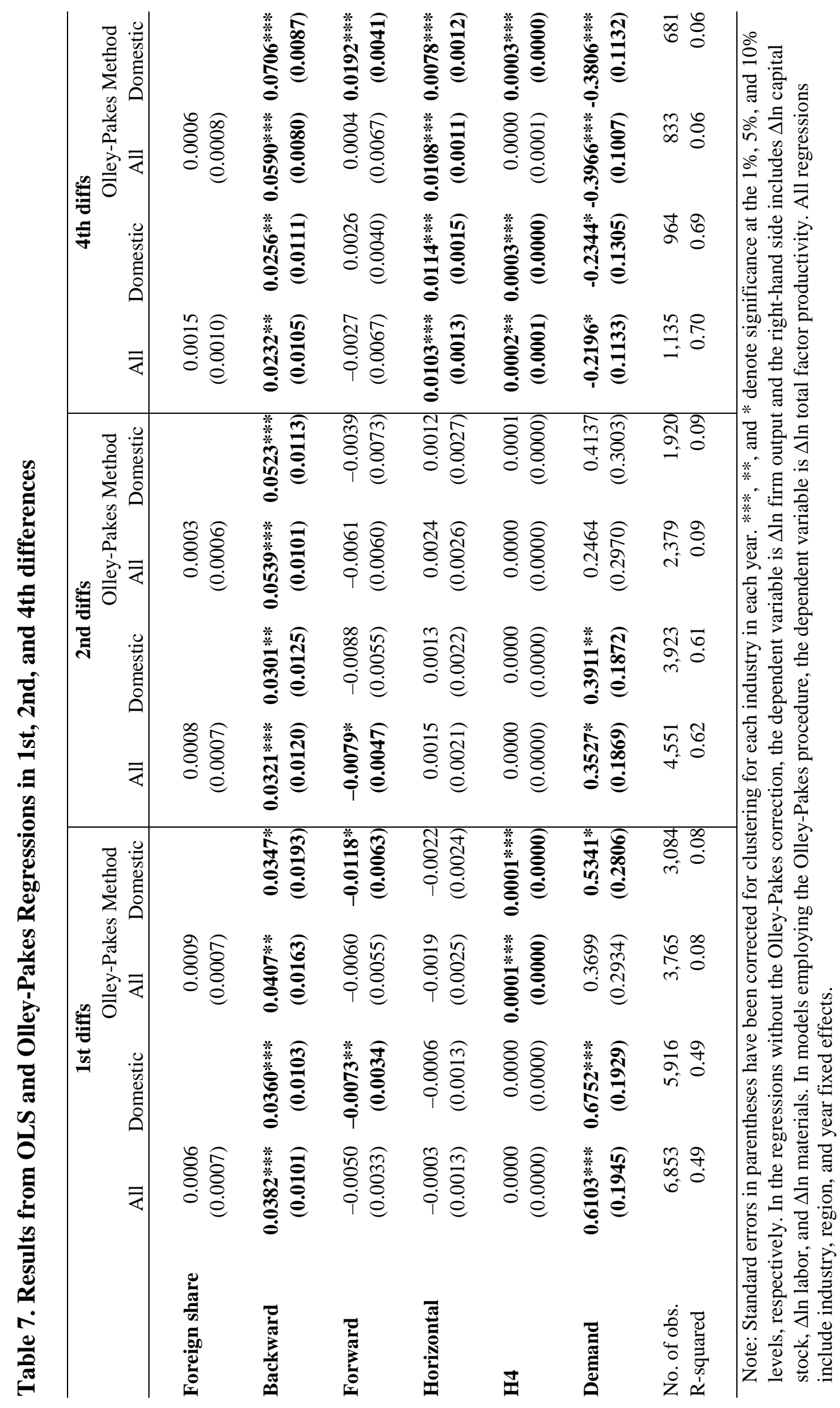




\section{Table 8. Share of Foreign Ownership and Productivity Spillovers}

\begin{tabular}{|c|c|c|c|c|}
\hline & \multicolumn{4}{|c|}{ 1st Diffs } \\
\hline & \multirow[b]{2}{*}{ All } & \multirow[b]{2}{*}{ Domestic } & \multicolumn{2}{|c|}{ Olley-Pakes Method } \\
\hline & & & All & Domestic \\
\hline Foreign share & $\begin{array}{r}0.0006 \\
(0.0007)\end{array}$ & & $\begin{array}{r}0.0010 \\
(0.0007)\end{array}$ & \\
\hline Backward (Partial Ownership) & $\begin{array}{r}0.0444 * * * \\
(0.0085)\end{array}$ & $\begin{array}{r}0.0394 * * * \\
(0.0096)\end{array}$ & $\begin{array}{r}0.0499 * * * \\
(0.0146)\end{array}$ & $\begin{array}{r}0.0401 * * \\
(0.0190)\end{array}$ \\
\hline Backward (Full Ownership) & $\begin{array}{r}0.0040 \\
(0.0110)\end{array}$ & $\begin{array}{r}0.0154 \\
(0.0133)\end{array}$ & $\begin{array}{r}0.0020 \\
(0.0171)\end{array}$ & $\begin{array}{r}0.0090 \\
(0.0223)\end{array}$ \\
\hline Forward & $\begin{array}{r}-0.0053 * \\
(0.0030)\end{array}$ & $\begin{array}{r}-0.0074 * * \\
(0.0032)\end{array}$ & $\begin{array}{l}-0.0066 \\
(0.0053)\end{array}$ & $\begin{array}{r}-0.0121 * \\
(0.0062)\end{array}$ \\
\hline Horizontal & $\begin{array}{l}-0.0009 \\
(0.0012)\end{array}$ & $\begin{array}{l}-0.0009 \\
(0.0012)\end{array}$ & $\begin{array}{l}-0.0025 \\
(0.0024)\end{array}$ & $\begin{array}{l}-0.0026 \\
(0.0023)\end{array}$ \\
\hline $\mathrm{H} 4$ & $\begin{array}{r}0.0000 \\
(0.0000)\end{array}$ & $\begin{array}{r}0.0000 \\
(0.0000)\end{array}$ & $\begin{array}{r}0.0001 * * * * \\
(0.0000)\end{array}$ & $\begin{array}{r}0.0001 * * * * \\
(0.0000)\end{array}$ \\
\hline Demand & $\begin{array}{r}0.6181 * * * \\
(0.1778)\end{array}$ & $\begin{array}{r}0.6817 * * * * \\
(0.1825)\end{array}$ & $\begin{array}{r}0.3794 \\
(0.2810)\end{array}$ & $\begin{array}{r}0.5427 * * \\
(0.2698)\end{array}$ \\
\hline No. of obs. & 6,853 & 5,916 & 3,765 & 3,084 \\
\hline R-squared & 0.49 & 0.49 & 0.08 & 0.08 \\
\hline F-stat $(\mathrm{BKFO}=\mathrm{BKPO})$ & 12.01 & 2.91 & 6.41 & 1.68 \\
\hline Prob $F>0$ & $\mathbf{0 . 0 0}$ & 0.09 & 0.01 & 0.20 \\
\hline
\end{tabular}


Table 9. Concentration in Downstream Sectors and Productivity Spillovers

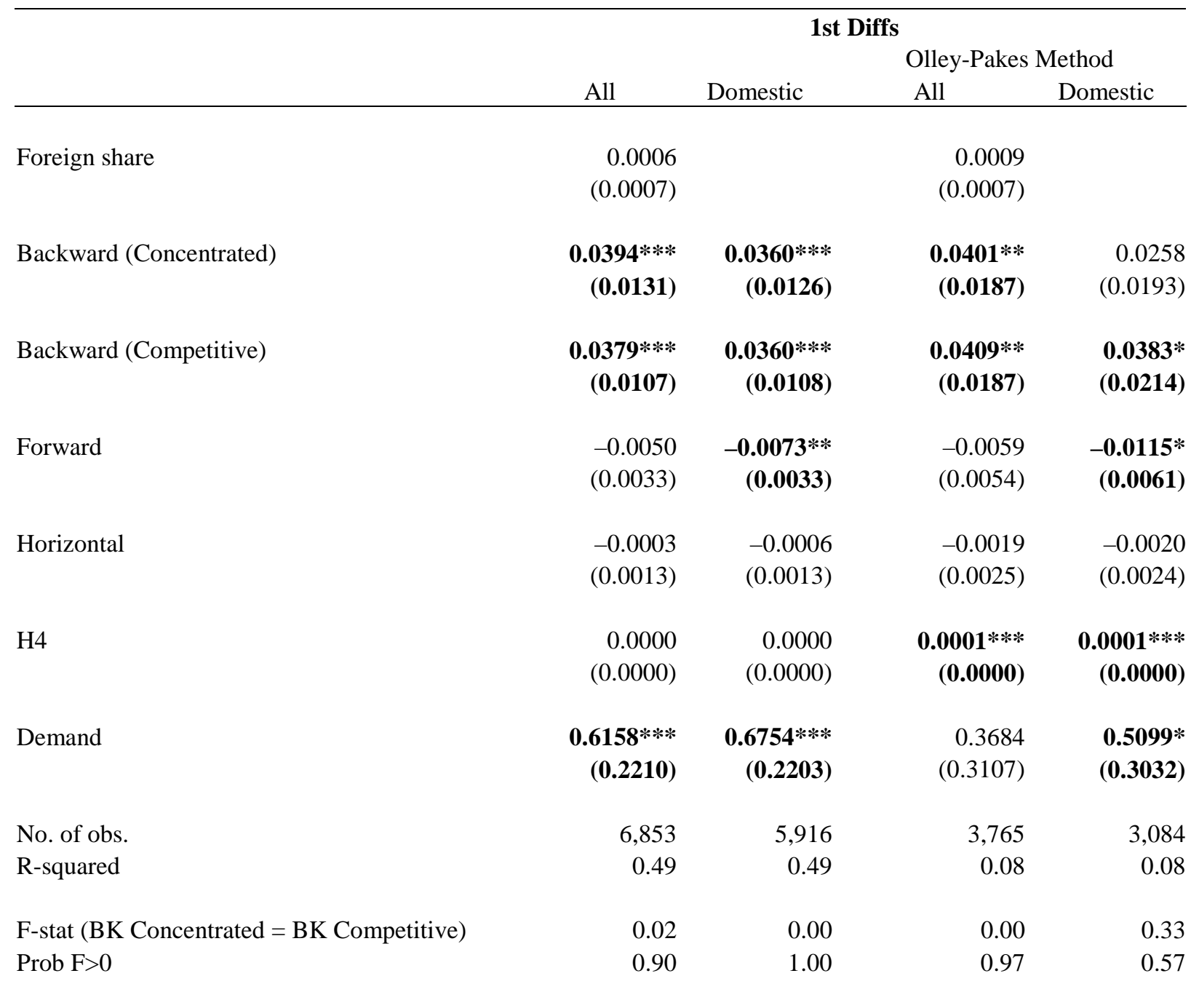

Note: Standard errors in parentheses have been corrected for clustering for each industry in each year. ***, **, and $*$ denote significance at the $1 \%, 5 \%$, and $10 \%$ levels, respectively. In the regressions without the OlleyPakes correction, the dependent variable is $\Delta \ln$ firm output and the right-hand side includes $\Delta \ln$ capital stock, $\Delta \ln$ labor, and $\Delta \ln$ materials. In models employing the Olley-Pakes procedure, the dependent variable is $\Delta \ln$ total factor productivity. All regressions include industry, region, and year fixed effects. BK $=$ Backward. 